\title{
THE OPTIMIZING OF RAHN SERVICE FOR THE DEVELOPMENT OF ISLAMIC BANKING IN INDONESIA
}

\author{
Lidia Rahmah Maulidia \\ Postgraduate Student of State Institute for Islamic Studies (IAIN) Sunan Kalijaga
}

\begin{abstract}
This paper considers rahn in classical figh with various opinions from Islamic schools of jurisprudence (madzhab). Here, one issue becoming debate among Moslem scholars is the use of mortgaged objects. Rahn is adopted by Islamic banking and becomes one of its services offered to the market. In practice, rahn appears as two different products. First, as a complementary product, that is additional transaction (guarantee/collateral) for other products such as ba'i al-murabahah financing. In this case, Islamic banks can detain debtors' mortgaged objects because of transaction. Second, as an independent product. In some Moslem countries including Malaysia, rahn has been being used as an alternative for the conventional pawnshop. Differing from that in conventional, in rahn debtors are not charged with interest. Instead, they are obliged to pay entrustment cost, conservancy cost, and custody cost, as well as appraisal cost. The main difference between such rahn costs and interest is, whereas interest can accumulate, costs of rahn can be paid once and specified in advance.

People interest toward conventional pawn service is exactly high because they had to get cash. This can be seen from the increase of pawnshop turnover from year to year. Rahn service is thus potential to be implemented and maximized. Logically, charged with high interest people still considering pawnshop as benefactor, much less Islamic banking with rahn service charging no interest. Hence, we are natural to optimistically introduce rahn service. Of course with manners and regulations that are free from the elements of riba.
\end{abstract}

\section{INTRODUCTION}

The term "rahn" is commonly used in figh al-muamalah, i.e. a chapter in Islamic law considering economic matters. Rahn means to detain debtor's certain properties as a guarantee or collateral for the loan debtor borrows. The detained properties must have economic values, so that detaining creditor has a guarantee to get back all of or a part of his receivable. ${ }^{1}$ Simply, we can say that rahn is a loan guarantee or pawning. ${ }^{2}$

Recently, Islamic banks adopt the rahn in two different forms, i.e. a guarantee

\footnotetext{
1 Syafi' i Antonio, Bank Syariah dari Teori ke Praktek, 1st printing (Jakarta: Gema Insani Press, 2001), pp. 182.

2 Attabik Ali and M. Zuhdi Muhdlor, Kamus Ashry, 3rd printing (Yogyakarta: PP Krapyak, 1998), pp. 996
}

for other financing and a product itself. ${ }^{3}$ In the latter form, Islamic banks may receive properties such as gold and other valuable goods for debts they lend.

Hence, we understand that Islamic banks work in similar ways with conventional pawnshop. Despite similarities, however, there are fundamental differences between the two. As Syafi'i Antonio said, ${ }^{4}$ among the differences is that in rahn, mortgagers or debtors charged with no interest but entrustment cost, conservancy cost, and custody cost, as well as appraisal cost. Here,

3 Concerning Bank Muamalat Indonesia (BMI)'s various products, there are two sources of information. First, a module for public titled as Produk-produk Perbankan Syariah: Sebuah Pengantar (Jakarta: BMI, 2000), pp. 32. Second, Laporan Tahunan 1999 BMI (Jakarta: BMI, 2000).

4 Syafi'i Antonio, Bank Syariah. pp. 184. 
whereas interest can accumulate, costs of rahn can be paid once and specified in advance.

The newest data mentioned that Perum Pegadaian (state-owned pawnshop) attains turnover up to IDR 5.6 billions in 2001, though the amount targeted was only IDR 4.2 billions. ${ }^{5}$ In 2002, Perum Pegadaian targets its turnover to grow up to IDR 6.6 billions (nearing 30 percent increase) and its profit to equal to IDR 60 millions. Viewing such an auspicious performance, Perum Pegadaian intends to expand its business by opening 40 new branches, i.e. 10 offices in Jakarta and peripheries and 30 offices in Kalimantan and Sulawesi islands. Thus, at the end of 2002, Perum Pegadaian will have 745 branch offices throughout Indonesia.

It is, of course, cheering up. What makes apprehensive is the fact that Islamic banks owning similar service (rahn) could not develop absolutely. If rahn is maximized, the development of Islamic banking will increase and Islamic banks will have additional profits, with which they can expand their networks and technology to maintain their operations.

\section{LOGICAL FRAMEWORK}

In Islamic view, it is legal to take profit. Profit is a payment for one's effort and risk. ${ }^{6}$ However, Islam does not require profit to be the only one purpose in economic activities. Earned profit must be based on the equity and proper principles. Pursuing profit unfairly and beyond the proper limits is considered to against the others' rights and exploits the society. ${ }^{7}$

5 Jawa Pos Daily, Friday, 4th January 2002, pp. 12.

6 M. Abdul Mannan, Islamic Economics: Theory and Practice, Indonesian translation by M. Nastangin (Jogjakarta: Dana Bhakti Wakaf, 1997), pp 133.

7 Ibid. See also Muhamad Nejatullah Shiddiqi, The Economic Enterprise in Islam, Indonesian translation by Anas Sidik (Jakarta: Bumi Aksara, 1991), pp. 46.
Profit is, according to Islam, different from interest. Therefore, Islam admits normal profit and prohibits interest. Viewing thoroughly, we know that transactions and profits in conventional pawn service and rahn are respectively quite different. In case of interest, creditors do not care about the use of money after it has been lent, as long as their interest is guaranteed. In case of profit, investors are still involved and concerned with the use of capital. While interest is not a result from a productive effort, profit is a result of production. Likewise, while in case of interest there is no risk (because interest is certain and fixed), in case of profit, the payment is given for the risk assumption by investors. It is this payment is uncertain and unknown in advance. ${ }^{8}$

Hence, rahn can be implemented, because it uses no interest but the principle of trusteeship. "Sesungguhnya Allah menyuruh kamu menyampaikan amanat kepada yang berhak menerimanya", means that Islamic banks have to return the mortgaged objects to the owner, and the owner of the objects have to pay for the services. This commitment must be applied in an actual deed because the purpose of human's life is not limited to terrestrial aims, but also the celestial ones.

\section{RAHN IN ISLAMIC FIQH The Definition of Rahn}

Ar-rahn in Arabic means al-tsubut wa al-dawam (fixed and eternal). Parts of Moslem scholars interpret ar-rahn as alhabs (detained). ${ }^{9}$ An example for this term is available in the Quran:

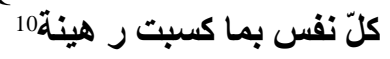

According to syara' (Islamic law), the definition of rahn is:

\footnotetext{
8 Mannan, Islamic ...., pp. 133.

9 Sayyid Sabiq, Fiqh Sunnah (Beirut: Dar al-Fikr,n.d.), III: 187.

${ }^{10}$ Qur'an surah al-Mudatsir: 38.
} 


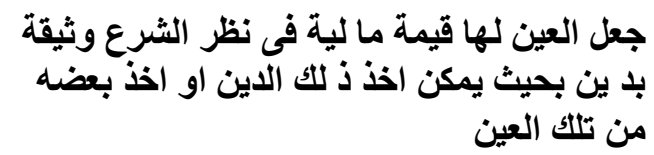

"To make an object with economic values in Islamic law perspective as a trust for the payment of debts, so that enabling mortgagee (murtahin) to get all or a part of the debts from the object"11

Ibn Qudamah provides the other definition:

$$
\begin{aligned}
& \text { المال الذي يجعل وثيقة بالدّ ين ليستو في من }
\end{aligned}
$$

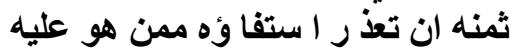

"An object made as a trust for the payment of debts, by which debts are met if the debtor could not pay to the creditor." 12

Moreover, Imam Abu Zakaria alAnshary defines rahn as:

$$
\text { تعذ رعل عين مال وثيقة با ين يستو فى منها عند }
$$

"To make an economic object as a trust for the payment of debts, from which unsettled debts are paid."13

Thus, we can assert that mortgage according to Islamic law means "detention", so that in mortgaging agreements the two parties have common responsibilities, i.e. to pay the debt for the debtors and to protect the mortgaged objects for the creditors. If the debt has been settled, the detention caused by the agreement is canceled, and the two parties are free from each responsibility.

The issue of mortgage is not only an issue for "modern society". In Islam, the history of mortgage has been being since the time of Prophet Muhammad. Bukhari reported two Hadist stating that:

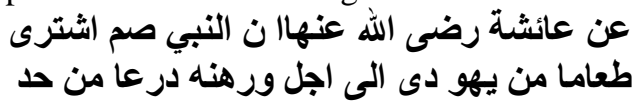

${ }^{11}$ Sayyid Sabiq, Fiqh.., III: 187.

${ }^{12}$ Imam Ibnu Qudamah, al Mughny (Riyadh: Maktabaha Riyad al Hadithah, t.t.), pp. 361.

13 Abi Zakariya al-Anshari, Fath al-Wahab (Singapura: Sulaiman Mariy, n.d.), pp. 192.
"From Aishah that Allah's Apostle bought some foodstuff from a Jew and mortgaged his armor to him."14

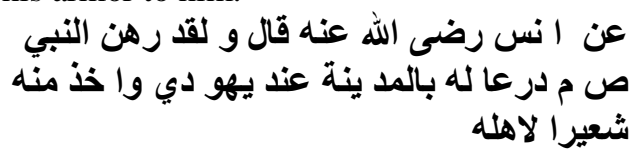

"From Anas that Allah's Apostle mortgaged his armor to a Jew in Madinah and bought barley bread from the Jew for his family."15

\section{Moslem Scholars' Opinions concerning Rahn}

From the above Hadist, we know that mortgage has a clear theological root in Islam. Hence, Moslem scholars consider these Hadist as a strong argumentation for the legality of pawn service.

On the following, we will discuss Moslem scholar's opinions concerning rahn and how is its legal status including the use of mortgaged object by each party involved in a rahn agreement.

According to Hasbi, mortgaged object is a trusteeship hold by mortgagee (one who lending debts and holding debtor's mortgaged property), and similar to other trusteeship, mortgagee needs not to compensate if the mortgaged object is damaged, as long as the case is not caused by his mistakes. ${ }^{16}$ At the same time, mortgagee could no use the mortgaged object for his own benefits. However, if mortgagee tries to utilize it, the expenditure is subtracted from the yields. The ways mortgagee can utilize the mortgaged land are to plant rice (if the land is a wet rice field) or another crops, or to gather and sell the fruits yielded as much as

\footnotetext{
14 Shahih Bukhari, No. 1926 Kitab al-Buyu'-Muslim, in CDROM Mausuah al-Hadis al-Sharif, ver. 1.2. Jami'ah al-Huquq Mahfudah Li Shikah Sharh Li Baramij Li al-Hisab.

15 Shahih Bukhari No. 1927, Kitab al-Buyu'-Ahmad, Nasai and Ibnu Majah.

16 Hasbi Ash-Shiddieqy, Hukum-hukum Fiqh Islam, 4th printing (Jakarta: Bulan Bintang, 1970), pp. 376.
} 
the expenditures. ${ }^{17}$ With such cultivation, mortgagee is permitted to derive benefits as much as the costs he expenses. The cultivation causes no impacts on the land and avoids the landowner from regrets.

It is concerning this matter is Moslem scholars disagree. Below are Moslem scholars' opinions on the issue.

\section{The Opinions of Imam Abu Hanifah (died 150/767).}

According Hanafiyah scholars, there is no difference between the uses of mortgaged object causing decrease in its price and not. As long as mortgager gives permission, the use of such mortgaged object by mortgagee is legal. If the mortgager sells the mortgaged object without permission from mortgagee, such a transaction will be considered as illegal, except the mortgager or debtor has settled his debts.

Hanafiyah scholars' opinions that party having the right to derive benefits from mortgaged object is mortgagee (with the obligation to pay the expenditures) are based on the Hadist:

\section{a. Hadist of Prophet Muhammad

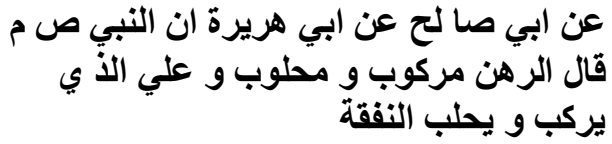

"From Abi Shalih from Abi Hurairah that Allah's Apostle said, 'The mortgaged animal can be used for riding as long as it is fed and the milk of the milch animal can be drunk according to what one spend on it. The one who rides the animal or drinks its milk should provide the expenditures'.,18

\footnotetext{
17 Rahmat Syafi'ie, "Konsep Gadai (ar-Rahn) dalam Fiqh Islam: Antara Nilai Sosial dan Komersial," in Chuzaimah T. Yanggo and Hafiz Anshary (ed.)., Problematika Hukum Islam Kontemporer, Third Book, 2nd printing (Jakarta: LSIK and Pustaka Firdaus, 1997), pp. 62.

18 Ibnu Qayyim al-Jauziyyah, I'lam al-Muwaqqi'in (Beirut: Daral-Jail, t.t.), II: 41.
}

There is another Hadist with a little different sentence:

$$
\begin{aligned}
& \text { الظهر يركب بنفقته اذا كان مرهونا ولبن الدهر } \\
& \text { يشرب بنفقته اذا كان مرهونا وعلي الأي يركب إنهان } \\
& \text { ويشرب النفقة }
\end{aligned}
$$

"The mortgaged animal may be used for riding, when it is mortgaged, on account of what is spent on it, and the milk of a milch animal may be drunk when it is mortgaged, and the expenditure shall be borne by him who rides (the animal) and drinks (the milk)." 19

Expenditure for the mortgaged object is mortgagee's responsibility. Since mortgaged object is in mortgagee's hands, and he pays the expenditure for it, then he may derive benefits from the object.

\section{b. Rational Explanation}

Agree with its functions as a collateral and trust for the payment of debts, mortgaged object is under mortgagee's authority. If mortgaged object is still held by mortgager or the debtor, its function as a collateral is none. If mortgaged object is neglected and unutilized by mortgagee, it means that the benefit is let to be lost, particularly when the mortgaged object requires expenditures for its maintenance.

Further, if mortgager has to go to mortgagee at every time for maintaining and taking benefit from the mortgaged object, it would lead to many expenses, particularly for mortgager. Likewise, if mortgagee has to maintain the mortgaged object and give the benefit to mortgager, it would lead to many expenses, particularly for mortgagee. It is therefore mortgagee's right to derive benefit from the mortgaged object, as he is the party holds such a collateral.

\footnotetext{
19 'Abd Muhsin Sulaiman Thahir, Ilaju al-Mushkilah al-Iqtisadiyah bi al-Islam, Indonesian translation by Anshari Umar S., 1st printing (Bandung: PT alMa’arif, 1985), pp. 180.
} 


\section{Comments on Hanafiyah's Opinions}

In interpreting the above Hadist, Imam Bukhari explains that party having the right to ride a mortgaged animal or to milk it is mortgagee. This contention supported by the second argument that, since mortgaged animal is held and under the authority of mortgagee, it is mortgagee's right to derive benefit from the animal.

However, writer has opinion that the above Hadist used by Abu Hanifah is only applicable for riding and milch animal, and not for other mortgaged objects. Concerning Imam Hanifah's second contention, it can surely collide with the function of mortgage, i.e. mortgaged object as a trust for the payment of debts and not a property. If we permit mortgagee to derive benefit, it will mean that we permit him to derive benefit from other's property.

Interestingly, Hanifah's contention allows mortgagee to derive benefit as long as the mortgager gave mortgagee permission to do so. Such a contention is very logical, as Hanifah lives in Baghdad, a place where the freedom of thought is largely followed. Hanifah's contention allowing mortgagee to derive benefit as long as the mortgager gave permission is based on the Hadist:

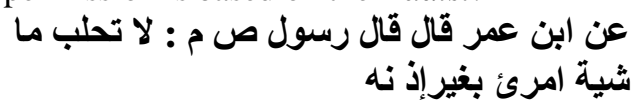

"From Ibnu Umar that Allah's Apostle said, 'One's animal should not be squeezed, except by its owner's permission'.,20

If we think logically, it seems true that there is a tendency to allow mortgagee to derive benefit form mortgaged object. Why? Since mortgagee's money is used and the benefit taken by mortgager or the debtor, then it is logical, that mortgagee takes benefit from debtor's mortgaged object.

${ }^{20}$ Al-Kahlani, Subulussalam (Bandung: Dahlan, n.d.), III: 51-52.
The Opinions of Imam Malik (died 179/795). Malikiyah scholars said that:

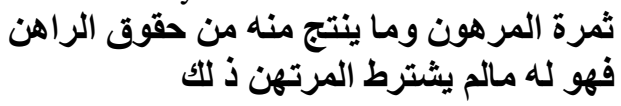

"Yield of mortgaged object, and everything derived from it, is mortgager's right. The yield for mortgager as long as mortgagee does not requisite."

It has been mentioned that mortgaged object functions as a trust for the payment of debts and not a mean for making profit. If we allow mortgagee to derive benefit from mortgaged object, it means that we allow him to derive benefit from other's property. Besides, if mortgagee takes benefit from mortgaged object, and the mortgaged object is a collateral for debts, it means that mortgagee takes benefit from the debts. Whereas, a Hadist states:

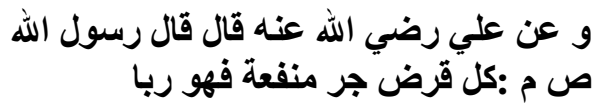

"Allah's Apostle said that whoever taking benefit from lending is riba."

Thus, Imam Malik contends that the benefit of mortgaged object is mortgager's or debtor's right and not mortgagee's or creditor's right. Mortgagee, however, may derive benefit with requisites:

1. The debts happen because of transaction and not an action intended to make profit. This is in case when a trader sells his good not by cash and requires buyer to mortgage an object suitable to the debts.

2. Mortgagee requisites that the benefit of mortgaged object is his right.

3. Time span for taking benefit is determined in advance. If the time span is not determined, the agreement will be considered as illegal.

Mortgagee's right in mortgage agreement is to detain mortgaged object until mortgager or debtor settled his obligation. 


\section{The Opinions of Imam Syafi'i}

In his book, al-Umm, Syafi'i said:

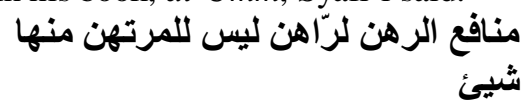

"The benefit of mortgaged object is debtor's, none of the mortgaged object is mortgagee's." 21

For Syafi'iyah scholars, there is a contention:

$$
\begin{aligned}
& \text { الرّاهن هو الصاحب الحق في منفعة المرهون }
\end{aligned}
$$

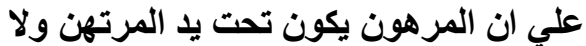

$$
\begin{aligned}
& \text { ترفع يده عنه الا عند الانتفاع بالمرهن يد المرنهن ون }
\end{aligned}
$$

"The man mortgaging an object is the party having the right on mortgaged object's benefit, though the mortgaged object is under mortgagee's authority. Here, mortgagee's authority on the object is retained except he takes benefit from it." 22

With the above stipulation, it is clear that party having the right to derive benefit from mortgaged object is mortgager or debtor and not creditor or mortgagee. Although the right to derive benefit from mortgaged object is in mortgager's hands, but the authority on the good is still in mortgagee's.

Syafi'i's argumentation is based on the Hadist:

\section{a. The First Hadist عن ابي هريرة عن النبي ص م قال: لا يظلق

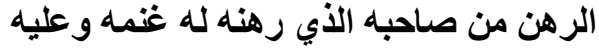 غرمه}

"From Abu Hurairah that Allah's Apostle said, 'mortgage does not avoid mortgager's right from the benefit of mortgaged object. The benefit is his, and he has responsibility on every possible risk." ${ }^{23}$

It is clearly mentioned in the Hadist that mortgaged object does not block the mortgager to derive benefit from the object. The man mortgaging the object still has the

\footnotetext{
21 Imam Syafi'i, Kitab al-Umm (t.t.p: t.p), III: 155

22 Abd Rahman Al-Jaziry, Madhahib....., pp. 333.

23 Imam Syafi'i, Al-Umm, pp. 167.
}

right on every benefit from mortgaged object and responsibility on every risk carried in the object.

\section{b. The Second Hadist

$$
\text { اللّ صم الرهن ابي هريرة رضي الله عنه قال رسول }
$$

"Mortgaged animal can be use for riding and the milk can be drunk." ${ }^{24}$

As-Syafi'i comments on the above Hadist as following:

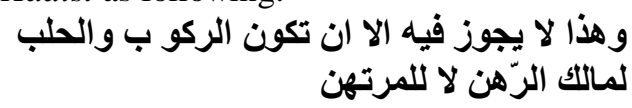

"And it is prohibited to ride or to milk (mortgaged animal) except for the owner, that is one mortgager and not mortgagee.",25

\section{c. The Third Hadist

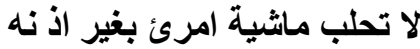

"One's animal should not be squeezed, except by its owner's permission." ${ }^{26}$

If mortgagee requires that the benefit of mortgaged object is his right and stated in the agreement, the agreement will considered as illegal. Thus, in every condition, mortgagee is not permitted to derive benefit from mortgaged object. The right to derive benefit is absolutely in mortgager hands. Mortgaged object is only a guarantee. If there are any damages, the risk will be burdened on the owner of the object or mortgager.

\section{Comments on Maliki's and Syafi'i's Opi- nions}

Both Maliki and Syafi'i refuse the utilization of mortgaged object by mortgagee, except by permission from the owner or mortgager who mortgaging the object. ${ }^{27} \mathrm{Abu}$

\footnotetext{
24 Al-Shaukani, Nail al-Autar (Beirut: Dar al-Fikr, n.d.), IV: 265.

25 Al-Syafi'i, Al-Umm, pp. 155.

26 Al-Kahlani, Subulussalam, pp. 51-52.

27 There is permission from mortgager. It is similar with Hanafi's opinion.
} 
Dawud and al-Bizzar consider Hadists used as argument by the two Moslem scholars as shahih. Thus, the right on the utilization of the object is still in the owner's hands.

Here, Imam Malik differentiates mortgaged objects, between animal and nonanimal and between usable for riding and not usable for riding. Despite the specific explanation on usable for riding and milking animal, the above Hadist could not be used as an argument for the other case. The use of such Hadist, as for Syafi'i and Malik, collides with qiyas in two aspects, i.e. allowing parties other than owner to derive benefit from an object and mortgagee's responsibility is adjusted to benefit, not to the price of mortgaged object.

\section{The Opinions of Imam Ahmad Ibn Hanbal (died 241/855)}

Hanbaliyah scholars consider the object itself, whether the mortgaged object is animal or non-animal, and whether the animal is usable for riding and milking or not.

$$
\begin{aligned}
& \text { المرهون اما ان يكون حيوانا يركب ويحلب او }
\end{aligned}
$$

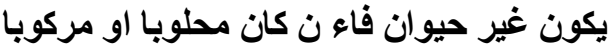

$$
\begin{aligned}
& \text { فلامرتهن ان ينتفع بركوبه ولبنه بغير اذن فئن } \\
& \text { الز اهن }
\end{aligned}
$$

"Mortgaged object is sometimes a usable for riding and milking animal and sometimes non-animal. If the mortgaged object is usable for riding animal, mortgagee will be allowed to derive benefit from the object by riding and milking the animal without permission from the owner who mortgaging it." 28

If the mortgaged object is not a usable for riding and milking animal, mortgagee will be allowed to derive benefit from the object by owner's voluntary permission, as long as the mortgage agreement is not caused by lending-borrowing transaction. If the reason for mortgaging is lendingborrowing transaction, mortgagee will be

\footnotetext{
${ }^{28}$ Abd Rahman Al-Jaziry, Madhahib ..., pp. 337.
}

forbidden to derive benefit from the object, though mortgager permits him to do so.

Another explanation given by Ibnu Qudamah $^{29}$ :

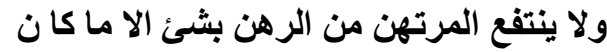

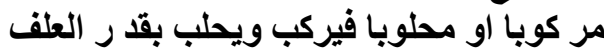

"Mortgagee is absolutely prohibited to take yield or benefit from mortgaged objects but a usable for riding and milking animal appropriate with the expenditure."

Further, Ibnu Qudamah explains that the derivation of benefit from mortgaged object is including:

(1) Condition needs no expenditure such as a house. In this case, mortgagee is prohibited to derive benefit from the object without permission.

(2) Condition needs expenditures. In this case, the legal status of mortgagee's utilization of mortgaged object by permission is as mentioned above.

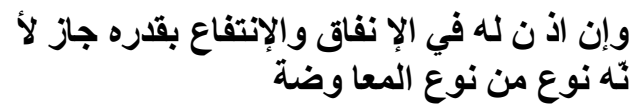

"If the owner mortgaging the object gives permission to mortgagee in maintaining and taking benefit from mortgaged object accordingly, it will be legal because it is considered as one of mu'awadah forms.",30

Thus, we can assert that: (a) For usable for riding and milking animals, mortgagee is allowed to derive benefit appropriating with expenditures. (b) For mortgaged objects other than usable for riding and milking animals, mortgagee is not allowed to derive benefit from the object.

Imam Hanbal's argumentation is based on the Hadist:

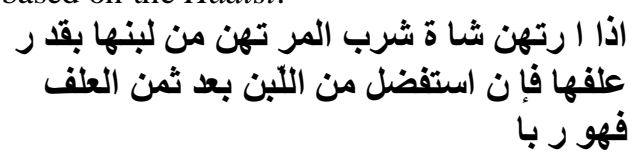

"If a sheep is mortgaged, mortgagee will be allowed to drink its milk appropriate with

29 Ibnu Qudamah, Al-Mughny, pp. 436.

${ }^{30}$ Ibid, pp. 427. 
the feed. If milk he drinks is more than the feed, it will be considered as riba." 31

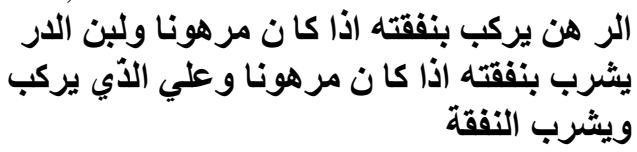

"The mortgaged animal can be used for riding as long as it is fed and the milk of the milch animal can be drunk according to what one spend on it. The one who rides the animal or drinks its milk should provide the expenditures." 32

Comments on Imam Ibn Hanbal's Opinions Imam Ahmad lays his contentions on genuine Hadist reported by Imam alBukhari. Hence, the position of such Hadist is strong and suitable for arguments.

The above two Hadist show that mortgagee is allowed to derive benefit from mortgaged object appropriate with the expenditures, though without permission from mortgager. However, the case is specific for only usable for riding and milking animals. Imam Ahmad, therefore, allows mortgagee to derive benefit from mortgaged object as stated in the Hadist and considers the opposite position for objects other than usable for riding and milking animals. Here, Imam Ahmad seems to choose a moderate position between Abu Hanifah, Imam Malik, and Imam Syafi'i, and to practice all arguments used by these two opposite parties.

These variances among Moslem scholars evidence their expertise in discussing the issues. Even their complicated thoughts evidence that in determining certain legal issues, they work very thorough and carefully. It is this attitude is important to follow in discussing issues related to conventional pawn service.

\section{CONVENTIONAL PAWNSHOP AND} RAHN IN BANKING PRACTICE

\footnotetext{
31 Al-Shaukani, Nail al-Autar, pp. 264.

32 Imam Bukhari, Sahih Bukhari (Singapura: Maktabah wa Matbaah, Suleiman Mariy, n.d.), pp. 78.
}

In Islamic banking practices, there are a range of products and services, such as wadiah, musyarakah, mudarabah, murabahah, bai' bitsaman ajil, bai' salam, ijarah wakalah, kafalah, rahn and qard. ${ }^{33}$ However, usually practiced products are so far limited to murabahah, bai' bitsaman ajil, mudarabah and musyarakah. Hence, questions arise: What factors are causing the problem? Does the other products and services not sold well? Do people still odd and hesitate to go to Islamic banking? Does hesitation surely appears among Islamic banks, concerning different opinions on the legal status of mortgaged good? Do Islamic banks pessimistically consider to the potential of rahn?

Actually, Indonesian society seems to have enthusiasm to rahn. This least of all represented by their needs of cash currently fulfilled from conventional pawnshop.

Irrespective of that, we need to discuss how rahn practiced by Islamic banks, particularly as an independent product. However, we need to also explain for a while the characteristics of conventional pawnshop.

Perum Pegadaian is a state owned firm servicing almost all of credits, both related to consumptive and productive purposes. The credits are offered for only short term (i.e. three to eight months), in a relatively small amount. ${ }^{34}$

Mortgage regulation prevails in pawnshop. Prospective debtor is obliged to mortgage his movable object as a collateral, along with mandate stating his permission for Perum Pegadaian to auction the object in case of his fail in settling the debts. Movable

\footnotetext{
33 See Syafi'i Antonio, Bank Syariah Suatu Pengenalan Umum, 1st printing (Jakarta: Tazkia Institut, 1999), pp. 121-188; Warkum Sumitro, Asas-Asas Perbankan Islam dan Lembaga-lembaga Terkait (BMUI dan Takaful di Indonesia), 1st printing (Jakarta: PTRajaGrafindo, 1996), pp. 31-47.

34 Subagyo et al., Bank dan Lembaga Keuangan Lainnya (Yogyakarta: STIE YKPN, 1999), pp. 89.
} 
objects include jewelries, electronics, and motorcycles, etc. ${ }^{35}$ Besides, other services are offered, such as depositing service, ${ }^{36}$ appraisal service, and gold selling counter.

The existence of pawnshop is much dependent on the determined interest. Even, as former Director of Perum Pegadaian, $\mathrm{Su}-$ harto, said, "pawnshop interest is still higher than that in banking system because Perum Pegadaian gets the money to be lent to consumers from banking loans", 37

Since having status as a state owned company (perusahaan umum) in 1990, Perum Pegadaian has been diversifying its product for consumers. The diversification includes the depositing service, appraisal service, Gallery 24 gold selling counter, and ONH gold coin. ${ }^{38}$ Recently, Perum Pegadaian is also considering Islamic pawn service.

Considering the urgent of pawn service and the height of interest rate prevails in conventional pawnshop, we need to pay more attention to pawnshop especially its legal status. This is logical as majority of Indonesian people are Moslems.

Satria Effendi considers pawn service practiced by Perum Pegadaian as different from that in Islamic jurisprudence (fiqh). In Islamic jurisprudence, the concept of mortgage or pawn is limited. According to Effendi, the reason for pawn service is mutual-assistance, and therefore, no payment is charged. ${ }^{39}$ Further, he states that

35 Ibid, pp. 88.

36 Depositing service is a service facility for valuable goods. This service is usually offered to those will have a journey for a relatively long time. See Subagyo, Bank..., pp. 93.

37 Luthfi Assyaukani, Politik, HAM dan Isu-isu Teknologi dalam Fiqh Kontemporer, 1st printing (Bandung Pustaka Hidayah, 1998), pp. 56.

38 S. Sutarto, "Strategi Penetapan Harga (Taksiran) dalam Menaikkan Omzet Kredit Perum Pegadaian," Paper to be presented in Seminar Regional Konstruksi Pegadaian dalam Perspektif Islam, BEM STIS at Gedung Wanitatama, 27th September 2001.

39 Luthfi Assyaukani, Politik, HAM... pp. 56 pawn service is legal as long as to be executed conventionally and involving no payment requisites. However, if there is extra payment for principal debts, the problem will not only related to pawn or mortgage, but also interest as that in banking system.

Satria's statement is of course different from that prevails in pawnshop. Pawnshop surely charges interest to mortgaged objects. So far, we can conclude that interest charged by pawnshop is forbidden because it is determined in advance and very high ( $d z a$ lim).

In Islamic banking, rahn is practiced as a complementary guarantee for other transactions. ${ }^{40}$ Fundamentally, the normative concept of murabah and salam needs no guarantee. However, Bank Muamalat Indonesia (BMI) considers that the prevailing of guarantee is permitted referring to the institution of rahn, though as an independent product, rahn itself is still unusually practiced by such an Islamic bank. ${ }^{41}$

In practicing rahn, BMI does not refer to one of Islamic schools of jurisprudence (madzhab). Hence, we need to investigate these schools. However, there are at least two different opinions on this matter. First, agreement among Islamic scholars that rahn can be practiced both in case of a journey and in case of a normal life (not a journey). The holy Quran states that:

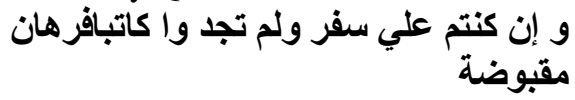

"And if you are upon a journey and you do not find a scribe, then a mortgage may be taken into possession". 42

Likewise, Hadist has been mentioned above states that Muhammad the Messenger

\footnotetext{
40 Here, referred to mainly the cases of BMI.

41 See the research of Muhammad Nur Yasin, Produkproduk Perbankan dalam Bank Muamalat Indonesia, unpublished thesis, IAIN Sunan Kalijaga Yogyakarta, 2001.

42 Surah al-Baqarah 283
} 
mortgaged his armor to a Jew and bought barley bread from him.

Second, according to al-Dahhak and his followers (madzhab Dhahiri), rahn can only be practiced in case of a journey. This madzhab refers to al-Baqarah $(2: 282)$ and ignores Hadist that has been mentioned above.

Related to the form of collaterals, Islamic banking requires money, goods, and warranties. However, there is a tendency that BMI prefers money for collaterals. This can be seen in National Islamic Law Council (DSN MUI)'s Regulation No. 13/DSNMUI/IX/2000 concerning the advance payment in murabahah, which signed by K.H. Sahal Mahfudz and Din Syamsuddin as Chairman and Secretary of MUI respectively. In this regulation asserted that: First, the importance of ensuring consumer seriousness in murabahah, i.e. permission for Islamic financial institutions (LKS) to charge their consumer with advance payment. Second, the amount of the advance payment is based on agreement between the two parties. Third, if consumer cancels murabahah agreement, he will have an obligation to compensate LKS with the advance payment. Fourth, if the amount of advance payment is less than LKS's loss, LKS will be allowed to request additional payment from consumer. Fifth, if the amount of advance payment is more than LKS's loss, LKS will have obligation to refund part of the payment to consumer.

Several reasons, such as practicality in recording, effectiveness in management, and ease in utilization is much dominating LKS's argument for the use of money as collaterals.

Different from BMI, Bank Syariah Mandiri applies rahn as an independent product. In November 2001, rahn is offered in Jakarta Mayestik and Thamrin branch offices. Here, mortgagers directed by BSM to use the money for business financing (productive purposes), though rahn for consumptive purposes is also offered. ${ }^{43}$

\section{THE PROSPECT OF RAHN IN ISLAM- IC BANKING}

From discussions above, we can conclude that rahn is practiced more frequently as an additional guarantee for other financing agreement, such as murabahah. This evidenced by the use of money rather than other goods as collaterals. Here, we can also say that Islamic bank does not develop classical fiqh, but Indonesian fiqh.

If rahn as an additional guarantee is practiced, why as an independent product is not? Islamic bank should be able to see this opportunity. There is a tendency in Indonesian society to choose quick loan facility, especially at the moment of happy Eid ulFithr and New Year festivals. It is ironic when rahn precisely practiced by Perum Pegadaian, and not by an Islamic bank. However, BSM's penetration should be appreciated. Hence, regulations concerning rahn (as an independent product similar to that in pawnshop) should be immediately arranged. Of course, it must be free from the elements of interest.

Some possible practices are recommended:

1. Al-qard ul-hasan and mudharabah agreements can be used in rahn. Alqard ul-hasan is used for those mortgaging goods for consumptive purposes. Debtors or mortgagers will pay bank or mortgagee for its services to keep mortgaged goods. Mudharabah is used for those mortgaging goods for productive purposes (investment financing or working capital). Debtors or mortgagers will share the profit according to proportion agreed in advance. Since the

\footnotetext{
43 www.tazkia.com, cited from Republika Online, Friday, 25th January 2002. The newest information states that rahn will be offered by BPRS al-Maksoem (BAMS) Rancaekek Bandung.
} 
amount of financing in rahn is referred to the value mortgaged goods, Islamic banks need to learn more from conventional pawnshop in appraising.

2. Capital needed for rahn is relatively much. Beside used for lending, capital also needed by an Islamic bank to invest lands and buildings (i.e. place for storing the mortgaged objects). Here, Islamic banks have to penetrate in order to get funds.

3. Trust investment. Public trust can be improved with good and fair servicing.

4. The socialization of rahn in mass media. Referring to Islamic banking in other Moslem countries including Malaysia on the ways they applying rahn.

\section{BIBLIOGRAPHY}

Antonio, Syafi'i (2000). Bank Syariah dari Teori ke Praktek. Jakarta: Gema Insani Press

, (1999). Bank Syariah Suatu Pengenalan Umum. Jakarta: Tazkia Institute.

Al-Anshary, Abi Zakariya (t.t.). Fath alWahab. Singapura: Sulaiman al-Mariy.

Al-Jaziry, Abd Rahman (t.t). Madhahib alArba'ah. Beirut: Dar al-Fikr.

Al-Kahlani (t.t.). Subulussalam. Bandung: Dahlan.

Al-Syafi' I (t.t.). Kitab al- Umm. T.p.

Assyaukani, Luthfi (1998). Politik, HAM dan Isu-isu Teknologi dalm Fiqh
Kontemporer. Bandung: Pustaka alHidayah.

AsShiddieqy, Hasbi (1970). Hukum Fiqh Islam. Jakarta: Bulan Bintang.

CD-ROM Mausuah al-Hadis al-Sharif Ver 1.2.

Al-Jauziyyah, Ibn Qayyim (t.t.). I'lam alMuwaqq'in. Beirut: Dar al-Jail.

Ibn Qudamah (t.t.). Al-Mughny. Riyadh: Maktabah Riyadh.

Mannan, Abdul (1997). Ekonomi Islam: Teori dan Praktik, Indonesian Translation. Yogyakarta: Dhana Bakti Wakaf.

Jawa Pos 4 Januari 2002.

Sabiq, Sayid (t.t.). Fiqh Sunnah. Beirut: Dar al-Fikr.

Shiddieqy, M. Nejatullah (1991). Kegiatan Ekonomi dalam Islam, Indonesian Translation. Jakarta: Bumi Aksara.

Subagyo, dkk (1999). Bank dan Lembaga Keuangan Lainnya. Yogyakarta: STIE YKPN.

Sutarto, "Strategi Penetapan Harga (taksiran) dalam Menakkan Omzet Kredit Perum Pegadaian," Paper to be presented in Seminar Regional Konstruksi Pegadaian Perspektif Islam, BEM STIS Gedung Wanitatama Yogyakarta 27 September 2001.

Yasin, M. Nur (2001). Produk-produk Perbankan dalam Bank Muamalat Indonesia, Unpublished Thesis, IAIN Sunan Kalijaga Yogyakarta. 